\title{
Toxoplasma gondii and Trichinella infections in wild boars (Sus scrofa) from Northeastern Patagonia, Argentina
}

\author{
Marina Winter ${ }^{\mathrm{a}, \mathrm{b}, *}$, Sergio D Abate ${ }^{\mathrm{a}}$, Mariana I Pasqualetti ${ }^{\mathrm{c}, \mathrm{d}}$, Fernando A Fariña ${ }^{\mathrm{b}, \mathrm{c}, \mathrm{d}}$, \\ Mariano E Ercole $^{\mathrm{c}}$, Lais Pardini ${ }^{\mathrm{b}, \mathrm{e}}$, Gastón Moré ${ }^{\mathrm{b}, \mathrm{e}}$, María Cecilia Venturini ${ }^{\mathrm{e}}$, Nélida Perera ${ }^{\mathrm{f}}$, \\ María José Corominas ${ }^{\mathrm{f}}$, Sergio Mancini ${ }^{\mathrm{f}}$, Bernardo Alonso ${ }^{\mathrm{g}}$, Andrea Marcos ${ }^{\mathrm{g}}$, Ricardo Veneroni ${ }^{\mathrm{g}}$, \\ Marianela Castillo $^{g}$, Diego E Birochio ${ }^{a}$, M Mabel Ribicich ${ }^{\text {c,d }}$ \\ ${ }^{a}$ Centro de Investigaciones y Transferencia Río Negro (CONICET-UNRN), Viedma, Río Negro, Argentina \\ ${ }^{\mathrm{b}}$ Consejo Nacional de Investigaciones Científicas y Técnicas, Argentina \\ ${ }^{\mathrm{c}}$ Universidad de Buenos Aires, Facultad de Ciencias Veterinarias, Cátedra de Parasitología y Enfermedades Parasitarias, Argentina \\ ${ }^{\mathrm{d}}$ CONICET-Universidad de Buenos Aires, Instituto de Investigaciones en Producción Animal (INPA), Argentina \\ e Laboratorio de Inmunoparasitología (LAINPA), Facultad de Ciencias Veterinarias, Universidad Nacional de La Plata, Argentina \\ ${ }^{\mathrm{f}}$ Unidad Regional de Epidemiología y Salud Ambiental- Laboratorio de Zoonosis, provincia de Río Negro, Viedma, Río Negro, Argentina \\ ${ }^{\mathrm{g}}$ Servicio Nacional de Sanidad y Calidad Agroalimentaria (SENASA), Argentina
}

A R T I C L E I N F O

\section{Keywords:}

Wild boar

Toxoplasma

Trichinella

Patagonia

Argentina

\begin{abstract}
A B S T R A C T
Wild boar (Sus scrofa) was introduced in many countries of the world and is recognized as carrier of many infectious diseases. Wild game meat consumption is recognized as a source of transmission of Toxoplasma gondii and Trichinella spp. The aim of the present study was to evaluate the prevalence of antibodies to T. gondii and Trichinella spp. in free-range wild boars in Northeastern Argentine Patagonia. Between 2014 and 2018, 144 blood samples and 423 muscle samples from 423 carcasses were collected. To detect $T$. gondii IgG, 144 sera were processed by an immunofluorescent antibody test, and to detect anti-Trichinella IgG, 125 sera and 304 muscle juice samples were processed by ELISA. Detection of first stage larvae in muscle was performed by artificial digestion. A total of 423 wild boars muscle samples were negative to Trichinella spp. by artificial digestion. Antibodies to Trichinella spp. were detected in $2.4 \%(3 / 125)$ of serum samples and in $1.64 \%(5 / 304)$ of meat juice samples. Antibodies to T. gondii infection were detected in $12.5 \%(18 / 144)$ of the serum samples. This is the first study to reveal the presence of antibodies to $T$. gondii in wild boars from Argentina. The present results suggest that consumption of raw or undercooked wild boar meat could represent a potential source risk for toxoplasmosis in humans and that Trichinella spp. is infrequent and/or that it circulates in low burdens among wild boars in Northeastern Patagonia.
\end{abstract}

\section{Introduction}

Wild boar (Sus scrofa) is an ungulate species that was introduced in many countries of the world. In Argentina, wild boar was introduced during Spanish colonization (Crosby, 1986). Also, around 1906, pure Eurasian wild boars were deliberately introduced for recreational hunting (Daciuk, 1978; Navas, 1987). Wild boar has a high adaptability to different environments and a wide tolerance to different climatic conditions. As it has happened in other countries, wild boars populations continue to increase and spread into new areas across Argentina (Merino and Carpinetti, 2003). Greater numbers of wild boars represent greater possibilities of interaction with livestock and humans (Massei et al., 2011; Castillo-Contreras et al., 2018). Hence, wild boar is recognized worldwide as a carrier of many pathogens, such as Toxoplasma gondii and Trichinella spp. (Ruiz-Fons et al., 2008; Meng et al., 2009; Wacheck et al., 2010), and recreational hunting and wild game meat

\footnotetext{
*Corresponding author at: Alem 665, Viedma, Río Negro, Argentina.

E-mail addresses: mwinter@unrn.edu.ar (M. Winter), sabate@unrn.edu.ar (S.D. Abate), mpasqualetti@fvet.uba.ar (M.I. Pasqualetti), fernandoaf@fvet.uba.ar (F.A. Fariña), mercole@fvet.uba.ar (M.E. Ercole), laispardini@gmail.com (L. Pardini), gastonmore@gmail.com (G. Moré), cventuri9@gmail.com (M.C. Venturini), agustina_30@hotmail.com (N. Perera), corominasm@gmail.com (M.J. Corominas), labzoonosisviedma@gmail.com (S. Mancini), balonso@senasa.gob.ar (B. Alonso), amarcos@senasa.gob.ar (A. Marcos), rlveneroni@gmail.com (R. Veneroni), mcastillo@senasa.gob.ar (M. Castillo), dbirochio@unrn.edu.ar (D.E. Birochio), mribicich@fvet.uba.ar (M.M. Ribicich).
} 
consumption have been highlighted as an emerging risk factor of transmission of foodborne parasites (Kijlstra and Jongert, 2008; Kapel and Fredensborg, 2015).

Toxoplasmosis and trichinellosis are parasitic zoonotic diseases with worldwide distribution. Toxoplasma gondii and Trichinella spiralis are in the "top ten" foodborne parasites by the FAO-WHO (FAO, 2014). Toxoplasmosis is considered a food-borne, soil-borne and water-borne disease. (Dubey, 2010; Hill and Dubey, 2015). T. gondii is an intracellular protozoon parasite with a facultative heteroxenous life cycle that infects domestic animals, wildlife and humans. Wild and domestic felids are the definitive hosts, while many mammals and avian species are intermediate hosts. Among intermediate hosts, wild boars are frequently exposed to $T$. gondii through ingestion of sporulated oocysts from the environment or by ingesting tissue cysts in prey or through scavenging, and result commonly infected (Bengis and Kock, 2002; Rostami et al., 2017). Some studies showed that the detection of $T$. gondii antibodies in wild boars is positively correlated with the presence of bradyzoites in their muscles (Bartová et al., 2006; Richomme et al., 2010). Currently there is no data on prevalence of T. gondii in wild boars of Argentina.

Trichinella spp. larvae have been reported in domestic and wild animals in all continents, except Antarctica (Dupouy-Camet et al., 2007; Pozio and Zarlenga, 2013). Wild and domestic animals become infected by feeding on Trichinella infected muscles from infected prey or through scavenging (Dupouy-Camet et al., 2007; Gajadhar et al., 2009; Pozio, 2013; Fariña et al., 2017). Up to now, 12 species and genotypes of the genus Trichinella are recognized in the world, and are grouped in two clades. The encapsulated clade, include T. spiralis, T. nativa, T. britovi, T. murrelli, T. nelsoni, T. patagoniensis; and three genotypes (Trichinella T6, T8 and T9), whereas the non-encapsulated clade, include T. pseudospiralis, T. papuae and T. zimbabwensis (Pozio and Murrell, 2006; Zarlenga et al., 2006; Krivokapich et al., 2012; Korhonen et al., 2016). Trichinella spp. muscle larvae have an anaerobic metabolism (Despommier, 1990) that allow their survival in decaying tissues and maintain their infective capacity (Fariña et al., 2016). Unlike other nematode infections that involve both wild and domestic animals, the biomass of Trichinella spp. is greater in wild than in domestic animals (Pozio, 2014). Wild boar is an important source of human trichinellosis worldwide (Rhee et al., 2011; Fichi et al., 2015; Holzbauer et al.,2014; Romano et al., 2011; Faber et al., 2015). In Argentina, trichinellosis is an endemic food-borne disease and an important Public Health problem (Pasqualetti et al., 2014). The aim of the present study was to evaluate the prevalence of antibodies to T. gondii and Trichinella spp. infection in free-range wild boars in Northeastern Argentine Patagonia.

\section{Materials and methods}

\subsection{Study area}

The study was carried out in Northeastern Argentine Patagonia, which includes the South of the province of Buenos Aires, and Northeast of the province of Rio Negro. This is a transitional area between Espinal (thorn shrub) and Monte (arid forest) regions (Roig et al., 2009). The extensive ecotone is characterized by the transition from xerophilous forest to xerophila shrub (Fosberg, 1961). The vegetation is distributed as shrub-graminous islands dispersed in a soil matrix with little or no vegetation cover (Aguiar and Sala, 1998). The herbaceous stratum is formed by winter growth grassland. Most of the area is private owned farmland, where the native vegetation alternates with semiextensive livestock (cattle, sheep and swine) and farming.

The weather is sub-temperate dry transition, with warm summers and moderate winters, and no seasonal excess of water. The rainy seasons are autumn and spring, however it can occasionally rain in winter. It is windy, especially in spring and summer (Bran et al., 2000). Average annual temperatures range from $10^{\circ}$ to $14^{\circ} \mathrm{C}$ (Rey et al., 1988).

Historically, more than $50 \%$ of the swine production in the study area and in Northern Patagonia is informal and without bromatological control. However, production and consumption are increasing (Boletín del Instituto Nacional de Tecnología Agropecuaria, 2019).

In addition, four species of wild felids have been reported in extraAndean Patagonia: Puma concolor, Leopardus geoffroyi, Leopardus colocolo and Herpailurus yaguarondi (Chebez et al., 2014), of which P. concolor has shown findings of Trichinella spp. (Ribicich et al., 2010a; Krivokapich et al., 2012).

As in other regions from Argentina and the world, wild boar has a high value as game animal species. They have been traditionally hunted in drive hunts by hunting teams with several dogs.

\subsection{Sample collection}

Between July 2014 and April 2018, 144 blood samples and 423 muscle samples were collected from 423 wild boars hunted during hunting seasons and in hunting tournaments (cross-sectional observational study with convenience sampling). Registered hunters are allowed to hunt between March and December in the province of Buenos Aires (Law 5786, decree 2578-1403/05, resolution 25) and between March and August in the province of Río Negro (Law 2056, decree 633/ 86, resolution 236). In most cases, hunters reported on the hunting location and the age of the animal. Wild boars were classified according to sex and to age groups as: piglets ( $\leq 6$ months of age), yearlings (6-12 months of age) and subadults or adults ( $>12$ months of age), according to body size and estimated weight (Zelman et al., 2018).

\subsubsection{T. gondii: antibody detection}

Serum samples were kept at $-20^{\circ} \mathrm{C}$ until analyzes. Sera from 144 (34.0\%) wild boars were analyzed by indirect immunofluorescent antibody test (IFAT). This test was already used with pig samples from Argentina and was available in our laboratories (Pardini et al., 2012). According to Basso et al. (2013), IFAT to detect IgG to T. gondii in swine samples has a sensitivity and specificity of $87.3(80.9 ; 92.8)$ and 87.0 (81.4; 91.8), respectively. Slides with cell cultured T. gondii tachyzoites of the RH strain were used as antigen. Sera were tested at 1:50 and 1:200 in phosphate buffer solution (PBS) dilutions, antipig IgG fluorescein isothiocyanate was used as conjugate (Sigma, USA). A titre of 50 was considered positive (Pardini et al., 2012). Positive and negative naturally infected pig sera were used as controls (Pardini et al., 2012; Basso et al., 2013).

\subsubsection{Trichinella spp.: parasite detection}

Muscle samples were collected and kept at $4{ }^{\circ} \mathrm{C}$ until artificial digestion. Ten grams of diaphragm pillars free of fat and fascia were tested by artificial digestion (AD) according to Gamble et al. (2000). In some cases, tongue and masseter muscles were added to diaphragm muscle to reach $10 \mathrm{~g}$.

\subsubsection{Trichinella spp.: antibody detection}

Serum and meat juice samples were kept at $-20{ }^{\circ} \mathrm{C}$ until analyzes. To detect anti-Trichinella IgG, 125 serum samples were examined with an indirect multi-species commercial E/S IDScreen ${ }^{\star}$ IDVet ELISA (19 serum samples were discarded due to poor quality/quantity). Meat juice was extracted from 304 wild boars muscle samples. Meat juice was obtained by allowing the samples to thaw at $4{ }^{\circ} \mathrm{C}$ for $24 \mathrm{~h}$ and were tested by E/S PrioCHECK ${ }^{\circ}$ ELISA. According to the manufacturers, both ELISA tests have high sensitivity and specificity, up to $100 \%$ (Buholzer et al., 2008). A total of 95 wild boars samples were analyzed by AD and both ELISA. Serum and meat juice samples were processed at 1:50 and 1:5 dilutions, respectively, proceeding according to manufacturer's instructions and using control sera supplied in the commercial kit.

\subsection{Statistical analysis}

The statistical analyzes were performed using the InfoStat 


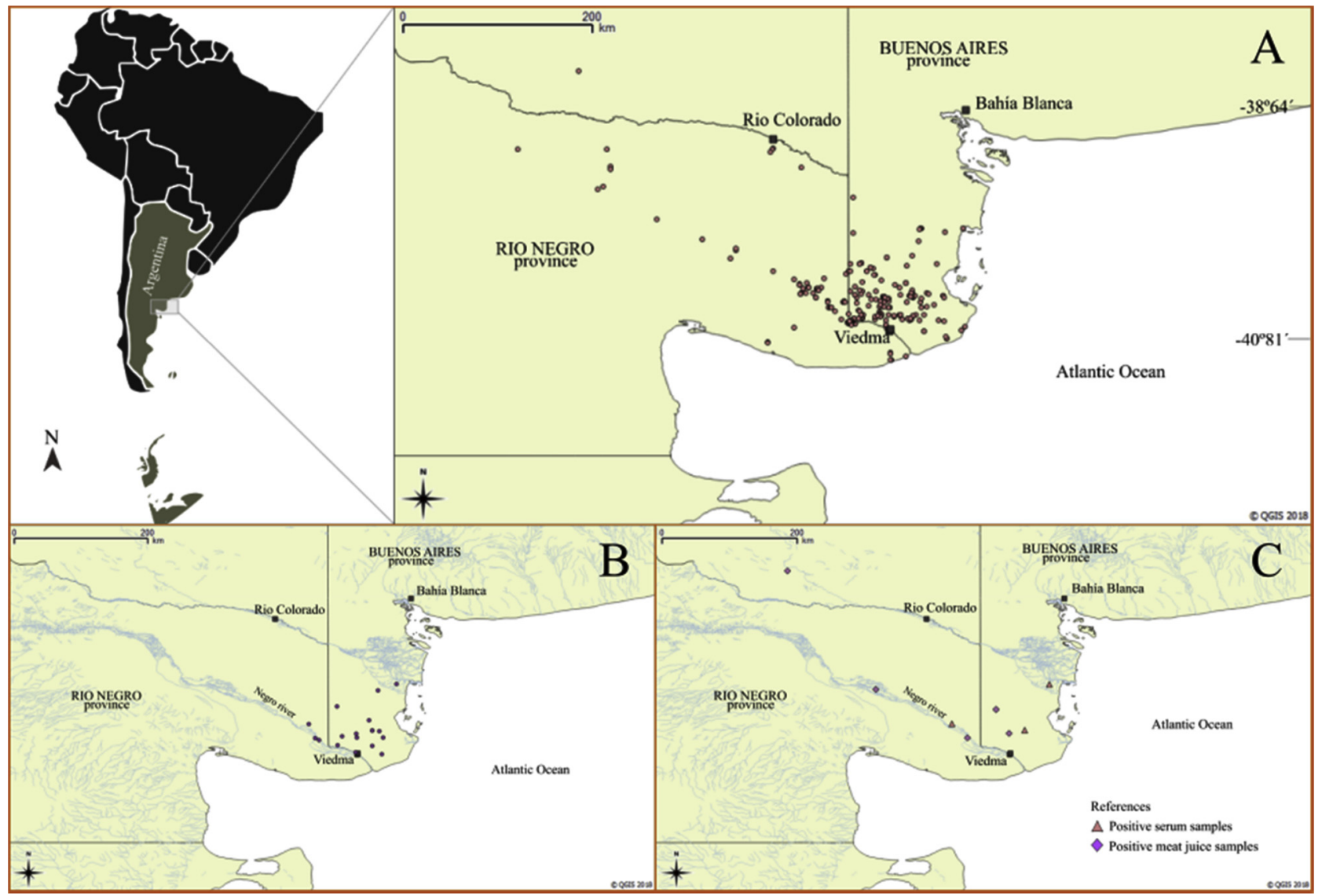

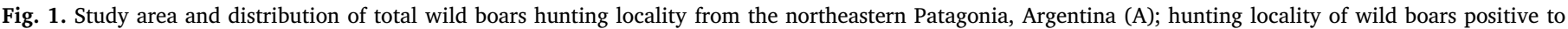
antibodies to T. gondii (B); hunting locality of wild boars positive to antibodies to Trichinella spp. (C).

statistical software (Version 2018p). Significant differences between AD and ELISA results, sex and age group was determined by Fisher's test for proportions with a confidence of $95 \%$.

\section{Results}

In five years, 423 wild boars carcasses were examined (2014 $\mathrm{n}=26,2015 \mathrm{n}=108,2016 \mathrm{n}=141,2017 \mathrm{n}=140,2018 \mathrm{n}=8$ ). From the total, 221 were males and 163 females (of 39, data of wild boars were not available), and 20 were classified as piglets, 57 yearlings and 225 subadults or adults (for 121 animals age was not determined). Fig. 1(A) shows the distribution of the hunting locations. Antibodies to T. gondii were detected in 18 (12.5\%; 95\% CI 6.56-18.44) serum samples (Fig. 1B). Positive results were obtained at serum dilutions of 1:50 in $11(61.1 \%)$ and 1:200 in $7(38.9 \%)$ wild boars samples. All muscle samples were Trichinella spp. negative by AD. Antibodies to Trichinella spp. were detected in 3 (2.4\%; 95\% CI $0.42-4.38)$ serum samples and in 5 (1.64\%; 95\% CI 0-3.24) meat juice samples (Fig. 1C). Distribution of positive samples to T. gondii and Trichinella spp. by sex is shown in Table 1. It was not possible to obtain muscle juice samples from the three Trichinella spp. positive wild boars sera. The availability of samples did not allow a correlation analysis of Trichinella spp. results between serological tests in serum and muscle juice results.

The statistical analysis showed that there are significant differences between $\mathrm{AD}$ and ELISA test ( $\mathrm{p} \leq 0.05 \%$; ELISA sera vs. AD $\mathrm{p}$ value $=$ 0.01 ; ELISA meat juice vs. $\mathrm{AD} p$ value $=0.01$ ). The difference between males and females for each pathogen and test was not statistically significant $(\mathrm{p} \leq 0.05$; ELISA sera $\mathrm{p}$ value $=0.16$; ELISA meat juice $\mathrm{p}$ value $=0.24$; IFAT $\mathrm{p}$ value $=0.1$ ), but there was significant difference when considering the total positive males and females ( $p \leq 0.05$; $p$ value $=0.000029$ ). Age had no significant effect on antibody seroprevalence to Trichinella and T. gondii. All the comparisons produced a $\mathrm{p}$ value $=1(\mathrm{p} \leq 0.05)$.

\section{Discussion}

Sus scrofa is one of the hundred worst invasive species (Lowe et al., 2000) and one of the most relevant wildlife species related to human and livestock health problems (Meng et al., 2009). Moreover it is the most important and widely distributed game animal species in the world (Massei et al., 2015).

The seroprevalence obtained to $T$. gondii antibodies in the present study is in agreement with the values reported by other authors in South America (Fornazari et al., 2009; Santos et al., 2016; Rostami et al., 2017). The difference among studies could be due to the use of different serological tests and cutoffs. The modified agglutination test (MAT) would have been the choice test but it was not commercially available in Argentina and the in-house method requires further development and validation. Nevertheless, the IFAT performed has shown a good sensitivity and specificity in swine samples (Basso et al., 2013). IFAT can be performed using a close related specie conjugate because antibodies cross-react to the IgG Fc fragment and it allows to detect, like in this case, specific Toxoplasma antibodies in wild boars using an anti-Pig IgG conjugate. Most T. gondii mammal infections are asymptomatic and chronic, where animals have tissue cysts and showed specific antibodies (Dubey et al., 2010). Therefore, seropositive animals could be considered potentially chronically infected. Because of their behavioral characteristics, wild boar is an important constituent of wildlife-livestock interface. It is unclear if $T$. gondii infection in wild boars primarily occurs by ingestion of oocysts from the environment or by ingestion of tissue cysts from prey meat or through scavenging. Nevertheless, free-living wild boars could be a good indicator for 
Table 1

Distribution of the analyzed wild boar samples according to sex and positivity for Trichinella spp. and Toxoplasma gondii.

\begin{tabular}{|c|c|c|c|c|c|c|c|c|c|c|c|c|}
\hline \multirow{4}{*}{$\begin{array}{l}\text { SAMPLE } \\
\text { Sex }\end{array}$} & \multirow{3}{*}{\multicolumn{3}{|c|}{$\begin{array}{l}\text { Parasite detection } \\
\text { AD Trichinella spp. } \\
\text { MUSCLE }\end{array}$}} & \multicolumn{9}{|c|}{ Antibody detection } \\
\hline & & & & \multicolumn{6}{|c|}{ ELISA Trichinella spp. } & \multirow{2}{*}{\multicolumn{3}{|c|}{$\begin{array}{l}\text { IFAT } T \text {. gondii } \\
\text { SERUM }\end{array}$}} \\
\hline & & & & \multicolumn{3}{|c|}{ MUSCLE JUICE } & \multicolumn{3}{|c|}{ SERUM } & & & \\
\hline & males & females & nd & males & females & nd & males & females & nd & males & females & nd \\
\hline $\mathrm{N}^{\circ}$ tested & 237 & 158 & 28 & 171 & 113 & 20 & 60 & 55 & 10 & 72 & 61 & 11 \\
\hline $\mathrm{N}^{\circ}$ positive & 0 & 0 & 0 & 5 & 0 & 0 & 3 & 0 & 0 & 12 & 4 & 2 \\
\hline$\%$ & - & - & - & $2.92^{\mathrm{a}}$ & - & - & $5^{\mathrm{b}}$ & - & & $16.67^{\mathrm{c}}$ & $6.56^{d}$ & $18.18^{\mathrm{e}}$ \\
\hline 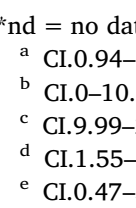 & & & & & & & & & & & & \\
\hline
\end{tabular}

monitoring environmental contamination with $T$. gondii oocysts in a given region (Bartová et al., 2006; Dubey et al., 2010). The prevalence of T. gondii in livestock in Northeastern Patagonia is unknown. The results obtained in wild boars could be indicating that $T$. gondii is also circulating in domestic animals from the study area. Therefore, this information is of high relevance because meat from infected animals is considered the most important source of $T$. gondii human infections (Hill and Dubey, 2015). In the province of Rio Negro, the prevalence of seropositive pregnant women to T. gondii in the last five years was between $8.28 \%$ (2013) and 2.95\% (2016) (Ministerio de Salud de la Provincia de Río Negro, Departamento Provincial de Estadística). Thus, these results suggest that wild boar meat or meat products consumed raw or undercooked are a potential risk of transmission of toxoplasmosis to humans in the study area. Additionally, the existence of four species of felids has been reported in the studied area, which could be related with the maintenance of $T$. gondii in the region, shedding oocyst which contaminate food or water (Dubey, 2010; Marcogliese, 2005).

In South America, trichinellosis is an endemic disease in Argentina and Chile (Ribicich et al., 2005). In Argentina, it is an important Public Health problem because of its high morbidity rates (Pasqualetti et al., 2014). In 2017, 91 cases of trichinellosis were confirmed (Boletín Integrado de Vigilancia, 2017), although it is recognized that there is a significant under-registration of the disease. Although most human outbreaks are related to the consumption of pork (Ribicich et al., 2005), in recent years the reported human cases of trichinellosis have been associated to the consumption of cougar (Puma concolor) or wild boar meat (Ribicich et al., 2010b; Pasqualetti et al., 2014). The global seroprevalence of host-Trichinella interaction in wild boars is 6\% (Rostami et al., 2018). Lauge et al. (2015) reported a prevalence of $3.4 \%$ (28/ 828 ) by $\mathrm{AD}$ among wild boars from the Northwest of the Argentine Patagonia. Natural ecosystems play an important role in the maintenance of Trichinella spp. in the environment. The differences observed in the results between wild boars from Northeast Patagonia and Northwest Patagonia could be explained by the differences between the ecosystems and the presence of large cultivated areas in the study location. In this sense, despite their feeding habits of scavenging on animal carcasses they would have less chance to consume animals infected with Trichinella larvae. Trichinella spp. negative results by AD are in line with the negative results reported for other wild species in the study area, like white-eared opossum (Didelphis albiventris), big hairy armadillo (Chaetophractus vellosus), Geoffroy's cat (Leopardus geoffroyi), lesser grison (Galictis cuja), Molina's hog-nosed skunk (Conepatus chinga) and South American grey fox (Lycalopex gymnocercus) (Winter et al., 2018).

For human consumption, the analytical sensitivity (one larva per gram) in wild animals may depend on the total amount of muscle analyzed. The amount of tissue recommended by the International Commission on Trichinellosis is $10 \mathrm{~g}$ (Gamble et al., 2000). The use of serological tests, such as ELISA, are considered adequate for surveillance and monitoring studies, due to their high sensitivity (detect antibodies with parasite burdens under 0.01 larva per gram) (Gamble et al., 2004). A total of 95 wild boars samples could be analyzed by artificial digestion and both indirect methods. Unfortunately the availability of samples did not allow a comparison of results between serological tests in serum and muscle juice for Trichinella spp. However, the different results obtained between AD and ELISA (in serum and meat juice samples) could be due to false positive results (Bruschi et al., 2019) or as a consequence of the fact that Trichinella spp. infects wild boars of Northeast Patagonia with a parasite burden under one larva per gram. Additionally, those seropositive wild boars could be infected by $T$. patagoniensis which induces a very low infection parasite burden in swine hosts (Krivokapich et al., 2012; Ribicich et al., 2013).

Although most of the reviewed studies showed no dietary differences between male and female wild boars (Loggins et al., 2002; Adkins and Harveson, 2006; Skewes et al., 2007), significant differences were found between proportions of seropositive males and females to the two foodborne parasites. All Trichinella spp. seropositive and $75 \%$ of $T$. gondii seropositive wild boars were male, probably due to the fact that in the studied location the males distribution area was greater than that of females, as reported in other countries (Saunders and Mc Leod, 1999), allowing scavenging and predation in different environments and with a broader range of hosts (Jolley et al., 2010; Giménez-Anaya et al., 2008). Also, according to rural inhabitants, it is easy to observe male wild boars feeding on live or dead livestock. In order to observe differences between age groups, it may be necessary to increase the number of wild boars sampled. However, it would be expected that the greatest seroprevalence would be among the older animals, understanding that they have been longer exposed (Pannwitz, et al., 2010).

This kind of studies contributes to the knowledge of two endemic foodborne pathogens in relation to a growing source of food exposure. Further studies need to be addressed to fully understand, in depth, the role of wild boar in the transmission of $T$. gondii and Trichinella spp. in Argentine Patagonia.

\section{Conclusion}

The relevance of this study resides in the fact that it is the first study to reveal the presence of antibodies to T. gondii in free-living wild boars of Argentina. More studies are needed to know in depth wild life cycle of T. gondii and Trichinella spp. in Argentine Patagonia. 


\section{Funding}

This study was supported by PICT № 2015/2350, PICT № 2015/ 3469, UBACyT20020130100336BA, PI UNRN2015 40-C-483 and PI UNRN2018 40-C-665.

\section{Conflict of interest}

I testify that none of the authors of our article "Toxoplasma gondii and Trichinella infections in wild boars (Sus scrofa) from the northeastern Patagonia, Argentina" has a financial or personal relationship with other people or organizations that could inappropriately influence or bias the paper entitled

\section{References}

Adkins, R.N., Harveson, L.A., 2006. Summer diets of feral hogs in the Davis Mountains, Texas. Southwest. Nat. 51, 578-580.

Aguiar, M.R., Sala, O.E., 1998. Interactions among grasses, shrubs and herbivores in Patagonia grass shrubs steppes. Ecologia. Austral. 8, 201-210.

Bartová, E., Sedlák, K., Literák, I., 2006. Prevalence of Toxoplasma gondii and Neospora caninum antibodies in wild boarss in the Czech Republic. Vet. Parasitol. 142, 150-153. https://doi.org/10.1016/j.vetpar.2006.06.022.

Basso, W., Hartnack, S., Pardini, L., Maksimov, P., Koudela, B., Venturini, M.C., Schares, G., Sidler, X., Lewis, F.I., Deplazes, P., 2013. Assessment of diagnostic accuracy of a commercial ELISA for the detection of Toxoplasma gondii infection in pigs by comparison with IFAT, TgSAG1-ELISA and Western blot, using a Bayesian latent class approach. Int. J. Parasitol. 43, 565-570. https://doi.org/10.1016/j.ijpara.2013.02. 003.

Bengis, R.G., Kock, R.A., Fischer, J., 2002. Infectious animal diseases: the wildlife/livestock interface. Rev. Sci. Tech. 21 (1), 53-65.

Boletín del Instituto Nacional de Tecnología Agropecuaria. https://inta.gob.ar/sites/ default/files/inta alder territorio porcino.pdf. (Accessed 20 February 2019).

Boletín Integrado de Vigilancia, 2017. Dirección Nacional de Epidemiología y Análisis de la Situación de Salud (391) ISSN 2422-698X.. Ministerio de Salud. (Accessed 29 January 2019). https://www.argentina.gob.ar/sites/default/files/biv_n391-se51. pdf.

Bran, D., Ayesa, J.A., Lopez, C., 2000. Áreas Ecológicas de Río Negro. Laboratorio de Teledetección-SIG INTA-EEA, Bariloche (Accessed 28 January 2019). http://sipan. inta.gob.ar/productos/ssd/rn/ae.htm.

Bruschi, F., Gómez-Morales, M.A., Hill, D.E., 2019. International Commission on Trichinellosis: Recommendations on use of serological tests for the detection of Trichinella infection in animals and man. Food Waterborne Parasitol. 12, e00032.

Buholzer, P., Price, P.C., Zwald, D., Haupt-Gerber, T., Bonilla, W., Raeber, A.J., 2008. PrioCHECK $^{*}$ Trichinella Ab, a newly highly sensitive and specific ELISA for the detection of antibodies against Trichinella spp. in serum and meat juice of pigs. In: Richey, M. (Ed.), 111th Meeting of the United States Animal Health Association. Rapid Solutions Group, Reno, Nevada Kansas City, Missouri, pp. 116-130. http:// www.usaha.org/upload/Proceedings/2007 USAHA Proceedings.pdf.

Castillo-Contreras, R., Carvalho, J., Serrano, E., Mentaberre, G., Fernández-Aguilar, X., Colom, A., González-Crespo, C., Lavín, S., López-Olvera, J.R., 2018. Urban wild boarss prefer fragmented areas with food resources near natural corridors. Sci. Total Environ. 615, 282-288. https://doi.org/10.1016/j.scitotenv.2017.09.277.

Chebez, J.C., Pardiñas, U., Teta, P., 2014. In: Massini, Vasquez (Ed.), Mamíferos Terrestres Patagonia Sur de Argentina y Chile, pp. 208 (Ciudad Autónoma de Buenos Aires).

Crosby, A.W., 1986. Ecological Imperialism: the Biological Expansion of Europe, 900901900. Cambridge University Press, New York 368 pp.

Daciuk, J., 1978. Estado actual de las especies de mamíferos introducidos en la Subregión Araucana (Rep. Argentina) y grado de coacción ejercido en algunos ecosistemas surcordilleranos. Anales de Parques Nacionales. 14, 105-130.

Despommier, D.D., 1990. Trichinella spiralis: the worm that would be virus. Parasitol. Today 6, 193-196.

Dubey, J.P., 2010. Toxoplasmosis of Animals and Humans, 2nd ed. CRC Press, Boca Raton, Florida $313 \mathrm{pp}$

Dupouy-Camet, J., Murrell, K.D., 2007. In: Dupouy-Camet, J., Murrell, K.D. (Eds.), FAO/ WHO/OIE Guidelines for the Surveillance, Management, Prevention and Control of Trichinellosis, Chapter 1.

Faber, M., Schink, S., Mayer-Scholl, A., Ziesch, C., Schönfelder, R., Wichmann-Schauer, H., Nöckler, K., 2015. Outbreak of trichinellosis due to wild boars meat and evaluation of the effectiveness of post exposure prophylaxis, Germany, 2013. Clin. Infect. Dis. 60 (12), 98-104. https://doi.org/10.1093/cid/civ199.

FAO, 2014. FAO identifies top 10 foodborne parasites. Vet. Rec. 175, 58 (Accessed 02 January 2019).

Fariña, F., Pasqualetti, M., Ilgová, J., Cardillo, N., Ercole, M., Aronowicz, T., Krivokapich, S., Kašný, M., Ribicich, M., 2016. Evaluation of the infectivity and the persistence of Trichinella patagoniensis in rotten guinea pig (Cavia porcellus) muscle tissue. Parasitol. Res. 116 (1), 371-375.

Fariña, F., Pasqualetti, M., Ilgová, J., Cardillo, N., Ercole, M., Aronowicz, T., Krivokapich, S., Kašný, M., Ribicich, M., 2017. Evaluation of the infectivity and the persistence of Trichinella patagoniensis in muscle tissue of decomposing guinea pig (Cavia porcellus).
Parasitol. Res. 116 (1), 371-375.

Fichi, G., Stefanelli, S., Pagani, A., Luchi, S., De Gennaro, M., Gómez-Morales, M.A. Pozio, E., 2015. Trichinellosis outbreak caused by meat from a wild boars hunted in an Italian region considered to be at negligible risk for Trichinella. Zoonoses Public Health 62 (4), 285-291. https://doi.org/10.1111/zph.12148.

Fosberg, F.R., 1961. Classification of vegetation for general purposes. Trop. Ecol. 2, 1-28.

Gajadhar, A.A., Pozio, E., Gamble, H.R., Nöckler, C., Maddox-Hyttele, C., Forbes, L.B., Vallée, I., Rossi, P., Marinculić, A., Boireau, P., 2009. Trichinella diagnostics and control: mandatory and best practices for ensuring food safety. Vet. Parasitol. 159 (3-4), 197-205. https://doi.org/10.1016/j.vetpar.2008.10.063.

Gamble, H.R., Bessonov, A.S., Cuperlovic, K., Gajadhar, A.A., Van Knapen, F., Noeckler, K., Schenone, H., Zhu, X., 2000. International commission on trichinellosis: recommendations on methods for the control of Trichinella in domestic and wild animals intended for human consumption. Vet. Parasitol. 93, 393-408.

Gamble, H.R., Pozio, E., Bruschi, F., NöcklerM, K., KapelM, C.M.O., Gajadhar, A.A., 2004. International commission on Trichinellosis: recommendations on the use of serological tests for the detection of Trichinella infection in animals and man. Parasite 11, 3-13. https://doi.org/10.1051/parasite/20041113.

Giménez-Anaya, A., Herrero, J., Rosell, C., Couto, S., García-Serrano, A., 2008. Food habits of wild boarss (Sus scrofa) in a Mediterranean coastal wetland. Wetlands 28 (1), 197-203.

Hill, D.E., Dubey, J.P., 2015. Toxoplasma gondii. Biology of Foodborne Parasites. CRC Press, pp. 209-222.

Holzbauer, S.M., Agger, W.A., Hall, R.L., Johnson, G.M., Schmitt, D., Garvey, A., Stromberg, B.E., 2014. Outbreak of Trichinella spiralis infections associated with a wild boars hunted at a game farm in Iowa. Clin. Infect. Dis. 59 (12), 1750-1756. https://doi.org/10.1093/cid/ciu713.

Jolley, D.B., Ditchkoff, S.S., Sparklin, B.D., Hanson, L.B., Mitchell, M.S., Grand, J.B., 2010. Estimate of herpetofauna depredation by a population of wild pigs. J. Mammal. 91, 519-524.

Kapel, C.M.O., Fredensborg, B.L., 2015. Foodborne parasites from wildlife: how wild are they? Trends Parasitol. 31 (4), 125-127. https://doi.org/10.1016/j.pt.2014.12.005.

Kijlstra, A., Jongert, E., 2008. Toxoplasma-safe meat: close to reality? Trends Parasitol. 24 18-22. https://doi.org/10.1016/j.pt.2008.09.008.

Korhonen, P., Pozio, E., La Rosa, G., Chang, B.C.H., Koehler, A.V., Hoberg, E.P., Boag, P.R., Tan, P., Jex, A.R., Hofmann, A., Sternberg, P.W., Young, N.D., Gasser, R.B., 2016. Phylogenomic and biogeographic reconstruction of the Trichinella complex. Nat. Commun. 7, 10513.

Krivokapich, S.J., Pozio, E., Gatti, G.M., Gonzalez Prous, C.L., Ribicich, M., Marucci, G., La Rosa, G., Confalonieri, V., 2012. Trichinella patagoniensisn. sp. (Nematoda), a new encapsulated species infecting carnivorous mammals in South America. Inter. J. Parasitol. 42 (10), 903-910. https://doi.org/10.1016/j.ijpara.2012.07.009.

Lauge, M.V., Prío, C., Montenegro, C., Monzón, L., Molinari, L., Mures, E., Vallejos, G., Chavez, B., Comin, H., Bengolea, R., Murcia, A., Bertrán, J., 2015. Triquinosis silvestre en el sur de la provincia del Neuquén, Argentina. SNS publicación periódica científico- tecnológica (9) ISSN 2314-2901.

Loggins, R.E., Wilcox, J.T., Van Vuren, D., Sweitzer, R.A., 2002. Seasonal diets of wild pigs in oak woodlands of the central coast region of California. Calif. Fish Game 88 (1), 28-34.

Lowe, S., Browne, M., Boudjelas, S., De Poorter, M., 2000. 100 Of the World's Worst Invasive Alien Species. A Selection From the Global Invasive Species Database. Published by The Invasive Species Specialist Group (ISSG) a specialist group of the Species Survival Commission (SSC) of the World Conservation Union (IUCN) $12 \mathrm{pp}$. First published as special lift-out in Aliens 12, December 2000. Updated and reprinted version: November 2004 (2000).

Marcogliese, D.J., 2005. Parasites of the superorganism: are they indicators of ecosystem health? Int. J. Parasitol. 35, 705-716. https://doi.org/10.1016/j.ijpara.2005.01.015.

Massei, G., Roy, S., Bunting, R., 2011. Too many hogs? A review of methods to mitigate impact by wild boars and feral hogs. Hum. Wild. Interactions 5 (1), 79-99.

Massei, G., Kindberg, J., Licoppe, A., Gačić, D., Šprem, N., Kamler, J., Baubet, E., Hohmann, U., Monaco, A., Ozolinš, J., 2015. Wild boars populations up, numbers of hunters down? A review of trends and implications for Europe. Pest Manag. Sci. 71 (4), 492-500. https://doi.org/10.1002/ps.3965.

Meng, X.J., Lindsay, D.S., Sriranganathan, N., 2009. Wild boarss as sources for infectious diseases in livestock and humans. Philos. Trans. R. Soc. Lond. B Biol. Sci. 364, 2697-2707. https://doi.org/10.1098/rstb.2009.0086.

Merino, M.L., Carpinetti, B., 2003. Feral pig Sus scrofa population estimates in Bahía Samborombón conservation area, Buenos Aires Province, Argentina. Mastozool. Neotrop. 10 (2), 269-275.

Navas, J.A., 1987. Los vertebrados exóticos introducidos en la Argentina. Revista del Museo Argentino de Ciencias Naturales, Serie Zoología, XIV. pp. 7-38.

Pannwitz, G., Mayer-Scholl, A., Balicka-Ramisz, A., Nöckler, K., 2010. Increased prevalence of Trichinella spp., Northeastern Germany, 2008. Emerg Infect Dis. 16 (6), 932-942. https://10.3201/eid1606.091629.

Pardini, L., Maksimov, P., Herrmann, D.C., Bacigalupe, D., Rambeaud, M., Machuca, M., Moré, G., Basso, W., Schares, G., Venturini, M.C., 2012. Evaluation of an in-house TgSAG1 (P30) IgG ELISA for diagnosis of naturally acquired Toxoplasma gondii infection in pigs. Vet. Parasitol. 189, 204-210. https://doi.org/10.1016/j.vetpar.2012. 04.014.

Pasqualetti, M., Acerbo, M., Miguez, M., Rosa, A., Fariña, F., Cardillo, N., Degregorio, O., Ribicich, M., 2014. Nuevos aportes al conocimiento de Trichinella y trichinellosis. Rev. Med. Vet. 95 (2), 12-21.

Pozio, E., 2013. The opportunistic nature of Trichinella- exploitation of new geographies and habitats. Vet. Parasitol. 194, 128-132. https://doi.org/10.1016/j.vetpar.2013. 01.037.

Pozio, E., 2014. Searching for Trichinella: not all pigs are created equal. Trends Parasitol. 
30 (1), 4-11. https://doi.org/10.1016/j.pt.2013.11.001.

Pozio, E., Murrell, K.D., 2006. Systematics and epidemiology of Trichinella. Adv. Parasitol. 63, 367-439. https://doi.org/10.1016/S0065-308X(06)63005-4.

Pozio, E., Zarlenga, D.S., 2013. New pieces of the Trichinella puzzle. Int. J. Parasitol. 43 (12-13), 983-997. https://doi.org/10.1016/j.ijpara.2013.05.010.

Rey, H.D., Quiroga, J.O., Moldes de Entraigas, B., Peronja, A., Suárez, G.N., Entraigas, J., Bustos, J.A., Cardone, E. (Eds.), 1988. Historia del Valle Inferior del Río Negro. El nuevo distrito federal. Plus Ultra, Bueno Aires, Argentina 250 pp.

Rhee, J.Y., Hong, S.T., Lee, H.J., Seo, M., Kim, S.B., 2011. The fifth outbreak of trichinosis in Korea. Korean J. Parasitol. 49 (4), 405. https://doi.org/10.3347/kjp.2011.49.4. 405.

Ribicich, M., Gamble, H.R., Rosa, A., Bolpe, J., Franco, A., 2005. Trichinellosis in Argentina: an historical review. Vet. Parasitol. 132, 137-142. https://doi.org/10 1016/j.vetpar.2005.05.042.

Ribicich, M., Gamble, H.R., Bolpe, J., Scialfa, E., Krivokapich, S., Cardillo, N., Betti, A., Cambiaggi Holzmann, M.L., Pasqualetti, M., Fariña, F., Rosa, A., 2010a. Trichinella infection in wild animals from endemic regions of Argentina. Parasitol. Res. 107, 377-380. https://doi.org/10.1007/s00436-010-1873-3.

Ribicich, M., Rosa, A., Bolpe, J., Scialfa, E., Cardillo, N., Pasqualetti, M.I., Betti, A., Fariña, F., Vizio, E., Gimenez, R., Pascual, G., Borrás, P., Aronowicz, T., 2010b. Avances en el estudio del diagnóstico y la prevención de la trichinellosis. Jornadas de la asociación argentina de parasitología Veterinaria XIX encuentro rioplatense de veterinarios endoparasitólogos.

Ribicich, M., Krivokapich, S., Pasqualetti, M., Gonzalez Prous, C.L., Gatti, G.M., Falzoni, E., Aronowicz, T., Arbusti, P., Fariña, F., Rosa, A., 2013. Experimental infection with Trichinella T12 in domestic cats. Vet. Parasitol. 194, 168-170. https://doi.org/10. 1016/j.vetpar.2013.01.047.

Richomme, C., Afonso, E., Tolon, V., Ducrot, C., Halos, L., Alliot, A., Perret, C., Thomas, M., Boireau, P., Gilot-Fromont, E., 2010. Seroprevalence and factors associated with Toxoplasma gondii infection in wild boars (Sus scrofa) in a Mediterranean island. Epidemiol. Infect. 138, 1257-1266. https://doi.org/10.1017/S0950268810000117.

Roig, F.A., Roig-Juñent, S., Corbalán, V., 2009. Biogeography of the Monte desert. J. Arid. Env. 73, 164-172. https://doi.org/10.1016/j.jaridenv.2008.07.016.

Romano, F., Motta, A., Melino, M., Negro, M., Gavotto, G., Decastelli, L., Pozio, E., 2011. Investigation on a focus of human trichinellosis revealed by an atypical clinical case after wild-boars (Sus scrofa) pork consumption in northern Italy. Jor Société Française de Parasitologie 18 (1), 85. https://doi.org/10.1051/parasite/2011181085.

Rostami, A., Riahi, S.M., Fakhri, Y., Saber, V., Hanifehpour, H., Valizadeh, S., Gholizadeh, M., Pouya, R.H., Gamble, H.R., 2017. The global seroprevalence ofToxoplasma gondii among wild boarss: a systematic review and meta-analysis. Vet. Parasitol. 244, 12-20. https://doi.org/10.1016/j.vetpar.2017.07.013.

Rostami, A., Riahi, S.M., Ghadimi, R., Hanifehpour, H., Hamidi, F., Khazan, H., Gamble, H.R., 2018. A systematic review and meta-analysis on the global seroprevalence of Trichinella infection among wild boarss. Food Control 91, 404-411. https://doi.org/ 10.1016/j.foodcont.2018.04.028.

Ruiz-Fons, F., Segales, J., Gortazar, C., 2008. A review of viral diseases of the European wild boars: effects of population dynamics and reservoirs role. Vet. J. 176, 158-169. https://doi.org/10.1016/j.tvjl.2007.02.017.

Santos, L.M.J., Farias, N.A., Oliveira, P., Gonzales Cademartori, B., Ramos, T., Oliveira, F.C., Lopez Ruas, J., 2016. Presence of Toxoplasma gondii infection in wild boars in southern Brazil. Sch. J. Agric. Vet. Sci. 3 (3), 238-241.

Saunders, G., Mc Leod, S., 1999. Predicting home range size from the body mass or population densities of feral pigs, Sus scrofa(Artiodactyla: Suidae). Aust. J. Ecol. 24, 538-543. https://doi.org/10.1046/j.1442-9993.1999.01001.x.

Skewes, O., Rodriguez, R., Jaksic, F.M., 2007. Trophic ecology of the wild boars (Sus scrofa) in Chile. Rev. Chil. Hist. Nat. 80, 295-307.

Wacheck, S., Fredriksson-Ahomaa, M., König, M., Stolle, A., Stephan, R., 2010. Wild boarss as an important reservoir for foodborne pathogens. Foodborne Pathog. Dis. 7 (3), 307-312. https://doi.org/10.1089/fpd.2009.0367.

Winter, M., Pasqualetti, M., Fariña, F., Ercole, M., Failla, M., Perello, M.D., Birochio, M., Abate, S., Soricetti, M., Ribicich, M., 2018. Trichinellosis surveillance in wildlife in northeastern argentine Patagonia. Vet. Parasitol. Reg. Stud. Reports. 11, 32-35. https://doi.org/10.1016/j.vprsr.2017.11.009.

Zarlenga, D.S., Rosenthal, B., La Rosa, G., Pozio, E., Hoberg, E.P., 2006. An old genus learns new tricks: late tertiary colonization and speciation of Trichinella nematodes among Eutheria. Proc. Nat. Acad. Sci. U. S. A. 103, 7354-7359.

Zelman, J., Drimaj, J., Heroldová, M., 2018. Habitat and management influence on a seasonal diet composition of wild boars. Biologia 73 (3), 259-265. https://doi.org/ 10.2478/s11756-018-0027-4. 